\title{
A NEW RECORDED SPECIES Begonia wenshanensis C.M. Hu ex C.Y. Wu \& T.C. Ku (Begoniaceae) FOR THE FLORA OF VIETNAM
}

Trinh Ngoc Bon ${ }^{1}$, Pham Thanh Trang ${ }^{2}$, Nguyen Van Dat ${ }^{3}$, Pham Van The ${ }^{*}$

${ }^{1}$ Vietnamese Academy of Forest Sciences, ${ }^{2}$ Vietnam National University of Forestry,

${ }^{3}$ Center for Environmental Counselling and Communication, ${ }^{4}$ Ton Duc Thang University

\begin{tabular}{|c|c|}
\hline ARTICLE INFO & ABSTRACT \\
\hline Received: $28 / 6 / 2021$ & \multirow{11}{*}{$\begin{array}{l}\text { Vietnam is one of the richest areas in the diversity of Begonia } \\
\text { (Begoniaceae) in Mainland Southeast Asia with more than } 90 \\
\text { recorded species. In this study, we recorded an additional species of } \\
\text { Begonia for the flora of the country. The specimens of newly recorded } \\
\text { species, Begonia wenshanensis C.M. Hu ex C.Y. Wu \& T.C. Ku were } \\
\text { collected from } 2019 \text { to } 2021 \text { in Phia Oac - Phia Den National Park of } \\
\text { Cao Bang Province, and Hoang Lien National Park of Lao Cai } \\
\text { Province. The characteristics of morphology, phenology, distribution } \\
\text { and ecology, collectively with colour illustrations of the newly } \\
\text { recorded species were provided. The morphology characters of the } \\
\text { plants in Phia Oac - Phia Den National Park show different with the } \\
\text { type specimens, the origin description, and the plants in Hoang Lien } \\
\text { National Park in glabrous outer petals, wider and cleft inner petals of } \\
\text { the staminate flowers. This research has contributed to the diverse } \\
\text { species of Begoniaceae in Vietnam up to } 93 \text { species. }\end{array}$} \\
\hline Revised: $14 / 9 / 2021$ & \\
\hline Published: 16/9/2021 & \\
\hline & \\
\hline KEYWORDS & \\
\hline Cao Bang & \\
\hline Lao Cai & \\
\hline National nark & \\
\hline National park & \\
\hline Plant diversity & \\
\hline Plant taxonomy & \\
\hline
\end{tabular}

\section{BỔ SUNG LOÀI Begonia wenshanensis C.M. Hu ex C.Y. Wu \& T.C. Ku (Begoniaceae) CHO HỆ THỬC VẬT VIẸT NAM}

\author{
Trịnh Ngọc Bon ${ }^{1}$, Phạm Thành Trang ${ }^{2}$, Nguyễn Văn Đạt ${ }^{3}$, Phạm Văn Thế ${ }^{*}$ \\ ${ }^{1}$ Viện Hàn lâm Khoa học Lâm nghiệp Việt Nam, ${ }^{2}$ Truòng Đại học Lâm Nghiệp, \\ ${ }^{3}$ Trung tâm Tu vấn và Truyền thông Môi trương, ${ }^{4}$ Truò̀ng Đại học Tôn Đức Thắng
}

\begin{tabular}{|c|c|}
\hline THÔNG TIN BÀI BÁO & \multirow{13}{*}{$\begin{array}{l}\text { TOM TAT } \\
\text { Việt Nam là một trong những khu vực giàu tính đa dạng các loài } \\
\text { Begonia (Begoniaceae) ở vùng Đông Nam Á lục địa với hơn } 90 \text { loài } \\
\text { đã được ghi nhận. Trong nghiên cứu này, chúng tôi ghi nhận thêm } \\
\text { một loài Thu hải đường cho hệ thực vật Việt Nam. Mẫu vật của loài } \\
\text { mới được ghi nhận, Begonia wenshanensis C.M. Hu ex C.Y. Wu \& } \\
\text { T.C. Ku được thu thập từ năm } 2019 \text { đến năm } 2021 \text { tại Vườn Quốc gia } \\
\text { Phia Oắc - Phia Đén tỉnh Cao Bằng và Vườn Quốc gia Hoàng Liên } \\
\text { tỉnh Lào Cai. Các đặc điểm về hình thái, hình thái học, phân bố và } \\
\text { sinh thái, cùng với các bản ảnh màu minh họa của loài mới ghi nhận } \\
\text { đã được cung cấp. Đặc điểm hình thái của các cây ở Vườn Quốc gia } \\
\text { Phia Oắc - Phia Đén thể hiện khác với mẫu chuẩn, mô tả gốc, và các } \\
\text { cây ở Vườn Quốc gia Hoàng Liên ở các cánh hoa ngoài nhẵn bóng, } \\
\text { các cánh hoa bên trong rộng hơn và xẻ thùy ở hoa đực. Nghiên cứu } \\
\text { này đã đóng góp cho sự đa dạng của họ Begnoniaceae lên đến } 93 \text { loài } \\
\text { ở Việt Nam. }\end{array}$} \\
\hline Ngày nhân bài: 28/6/2021 & \\
\hline & \\
\hline Ngày hoàn thiện: 14/9/2021 & \\
\hline Ngày đăng: 16/9/2021 & \\
\hline TÙे KHÓA & \\
\hline IU КНUA & \\
\hline Cao Bằng & \\
\hline Lào Cai & \\
\hline Vườn Quốc gia & \\
\hline & \\
\hline Đa dạng thực vật & \\
\hline Phân loại thực vật & \\
\hline
\end{tabular}

DOI: $\underline{\text { https://doi.org/10.34238/tnu-jst.4703 }}$

\footnotetext{
${ }^{*}$ Corresponding author. Email: phamvanthe@tdtu.edu.vn
} 


\section{Introduction}

Begonia L. (Begoniaceae) is one of the ten largest genera of Angiosperms with approximately 1,600 accepted species names, widely distributed in the tropical and subtropical regions [1]-[5]. Mainland Southeast Asia probably is one of the richest areas in the diversity of Begonia with more than 110 discovered species [1], [6]-[9]. In recent years, many new species of Begonia have been described from Vietnam, making the total recorded species over 90 species in the country [4], [6], [7], [9]-[14]. The characteristics of herbs or subshrubs, tuberous or creeping rhizomes, simple leaves, free stipules, monoecious flowers, 2-5-tepal, angled or winged of 3locular ovary, 2-6-style, branched and often twisted stigmatic, a capsule or berry fruit, and numerous seeds are typical of Begonia [5].

While conducting the Nagao Natural Environment Foundation "Bio-ecological Nature Conservation Project in Mountainous Region in Northern Vietnam" project, we found a strange plant population of Begonia in Phia Oac - Phia Den National Park, Cao Bang province. Hence, some specimens were collected later in June 2020 and June 2021. In addition, a similar morphology plant population was also discovered in Hoang Lien National Park, Lao Cai province in 2019. After critical examination, consulting relevant literature, the specimens were identified as Begonia wenshanensis C.M. Hu ex C.Y. Wu \& T.C. Ku. This species has been recorded from China but has never been reported from Vietnam to date [15].

\section{Methodology}

The fresh specimens of Begonia wenshanensis and photographs were collected and taken from the wild from 2019 to 2021 in Hoang Lien and Phia Oac - Phia Den National Parks of Lao Cai and Cao Bang provinces, respectively. The collection and fixing specimens followed the usual procedures for botanical specimens [16], [17]. Identification and morphological description were based on $\mathrm{Hu}$ [15], and Shui et al. [4]. The analysis of specimens was taken in Silviculture Research Institute and deposited at VAFS. Type and other specimens of Begonia wenshanensis were accessed from E Virtual Herbarium (acronyms according to Thiers [18]).

\section{Results and Discussion}

The characteristics of morphology, phenology, distribution and ecology, accompanied with colour illustrations of Begonia wenshanensis were provided as shown below.

Begonia wenshanensis C.M. Hu ex C.Y. Wu \& T.C. Ku - Thu hải đường Văn Sơn

Acta Phytotax. Sin. 33(3): 262-263 (1995).

Types. CHINA: Yunnan Province, Wen-Shan-Hsien, Maa-luh-tarng, in mixed forests, moist environments along streams, flowers pinkish-rose, $2200 \mathrm{~m}$ alt., 17 August 1947, K.M. Feng 11323 (Holotype: PE; Isotypes: KUN, E00022104!)

Description: Monoecious rhizomatous herb, up to $32 \mathrm{~cm}$ tall, sparsely hairy. Rhizome stout, creeping, pinkish-green, $8-15 \mathrm{~mm}$ in diam., internode up to $10 \mathrm{~cm}$. Stipules persistent, greenishpink, sparsely hairy, caducous, keeled, ovate-lanceolate, $8-9 \times 3-4 \mathrm{~mm}$, apex acute, margin entire. Leaves alternate, petiole terete, pale pink, petiole $1.5-10 \mathrm{~cm}$ long, $1.5-4 \mathrm{~mm}$ in diam., subglabrous, erect or ascending; blade ovate, asymmetric, 7-13 $\times 2.7-6 \mathrm{~cm}$, base oblique, cordate, apex acuminate, margin irregularly denticulate, very shallowly lobed, adaxial surface dark green, abaxial surface pale green, both surfaces sparsely hispidulous; venation basally ca. 6 palmate, midrib distinct, prominent in abaxial surface, approaching the leaf margin, ca. 5 secondary veins on each side, minor veins reticulate. Inflorescences axillary, 2-7-flowered, cyme, arising directly from stem, branched ca. 2 times; peduncle reddish to pale yellow-green, 4.5-8 cm long, 1-1.5 mm in diam., glabrous. Bracts deciduous, pink greenish, abaxial sparse hairy, lanceolate, 5-9 $3 \mathrm{~mm}$, upper bracts smaller. Staminate flowers: pedicel $1.1-1.3 \mathrm{~cm}$, ca. 1 $\mathrm{mm}$ in diam., glabrous; tepals 4 , white pinkish to reddish, two whorls, outer 2 widely ovate to 
broadly ovate, apex acute, base rounded, $1.3-1.4 \times 0.6-1.1 \mathrm{~cm}$, abaxially glabrous or villous, inner 2 narrowly elliptic to ovate, ca. 7-8 $\times 0.4-6 \mathrm{~mm}$, margins entire or cleft, teeth $2-4$; androecium actinomorphic, ca. $0.4 \mathrm{~cm}$ across, stamens golden yellow, ca. 50; filaments ca. $1 \mathrm{~mm}$ long, fused at the base into a column ca. $2 \mathrm{~mm}$ long; anthers oblong, $1-1.5 \mathrm{~mm}$ long, ca. $1 \mathrm{~mm}$ in diam. Pistillate flowers: pedicel $1.3-1.8 \mathrm{~cm}$; tepals 3 , white pinkish to reddish, two whorls, unequal, glabrous, outer 2 broadly ovate, 7.5-9.5 $\times 6.5-7.5$, apex subacute, base rounded, inner 1 broadly oblanceolate to elliptic, ca. $6 \mathrm{~mm}$ long, $3 \mathrm{~mm}$ wide; ovary narrowly trigonous-ellipsoid, glabrous, 3-locular, $6 \mathrm{~mm}$ in length, $4 \mathrm{~mm}$ thick (wings excluded), white pinkish to reddish, 3winged, wings unequal, apex obtuse, protruding, 2-lateral smallest 7-9 mm long, 1-2 mm tall, 1 above largest 10-12 $\mathrm{mm}$ long, 4-6 mm tall; styles 3, fused at base, golden yellow, ca. $3 \mathrm{~mm}$ tall, ca. $2 \mathrm{~mm}$ wide, lobe 2-divided, opposite spiralled. Capsule 3-locular, immature fruit ca. $1 \mathrm{~cm}$ long and wide, wings 3, unequal, triangular; seed many, oblong, ca. $1 \mathrm{~mm}$ (Figure 1 - 2).

Phenology: Flowering and fruiting in June to November

Distribution and Ecology: It grows common shady in wet places along streams in evergreen broad-leaved forests mixed bamboo at an elevation of 1650-1850 $\mathrm{m}$ a.s.l. Some shrubs, herbaceous and tree species could be found in the area such as Adina pilulifera, Adinandra annamensis, Aucuba sp., Carex sp., Clematis buchananiana, Crawfurdia pasquieri, Cryptocarya hainanensis, Elatostema atropurpureum, Euonymus laxiflorus, Geophila repens, Lysionotus serratus, Magnolia lanuginosa, Magnolia fordiana var. hainanensis, Olea dioica, Ophiopogon reptans, Paris caobangensis, Polygala sp., Pteris sp., Rubus sp., Schefflera ciliata, Siliquamomum tonkinense, Sinarundinaria sp., Smilax sp., Strobilanthes sp., and Tectaria sp. Currently, Begonia wenshanensis is discovered in two small populations in Phia Oac - Phia Den National Park of Cao Bang province, and Hoang Lien National Park of Lao Cai province. In other areas, the species was recorded in Yunan, China [15].

Notes: The morphology characters of the plants in Phia Oac - Phia Den National Park show different with type specimens, origin description, and the plants in Hoang Lien National Park in glabrous outer petals, wider and cleft inner petals of the staminate flower.

Specimens examined: VIETNAM. Cao Bang province, Phia Oac - Phia Den National Park, humid primary forest slightly impacted, alt. 1850m, around points N22 3651.7 E105 51 52.1, 4 June 2020, Trinh Ngoc Bon, Pham Van The, Phan Ke Loc, Vu Thuy Duong, TB 243 (VAFS!); Lao Cai province, Hoang Lien National Park, alt. 1820m, around points E22.238013, N103.911959, 5 October 2019, Hoang Thanh Son, Pham Thanh Trang, Ly Ta Chun \& Hoang Manh Quyen TV201905 (VAFS!).

\section{Conclusion}

With the additional result from this study, a total of 93 species of Begonia were recorded for the Flora of Vietnam. On the other hand, Begonia wenshanensis in Cao Bang province is slightly different in morphology from the population in Lao Cai province. To understand this aspect, future study on molecular could be implemented.

\section{Acknowledgements}

The authors would like to thanks C. W. Lin, Taiwan Forestry Research Institute for the identification. The finance of this research was supported by Nagao Natural Environment Foundation, Japan. The project was organized and implemented by VNU-Central Institute for Natural Resources and Environmental Studies. 

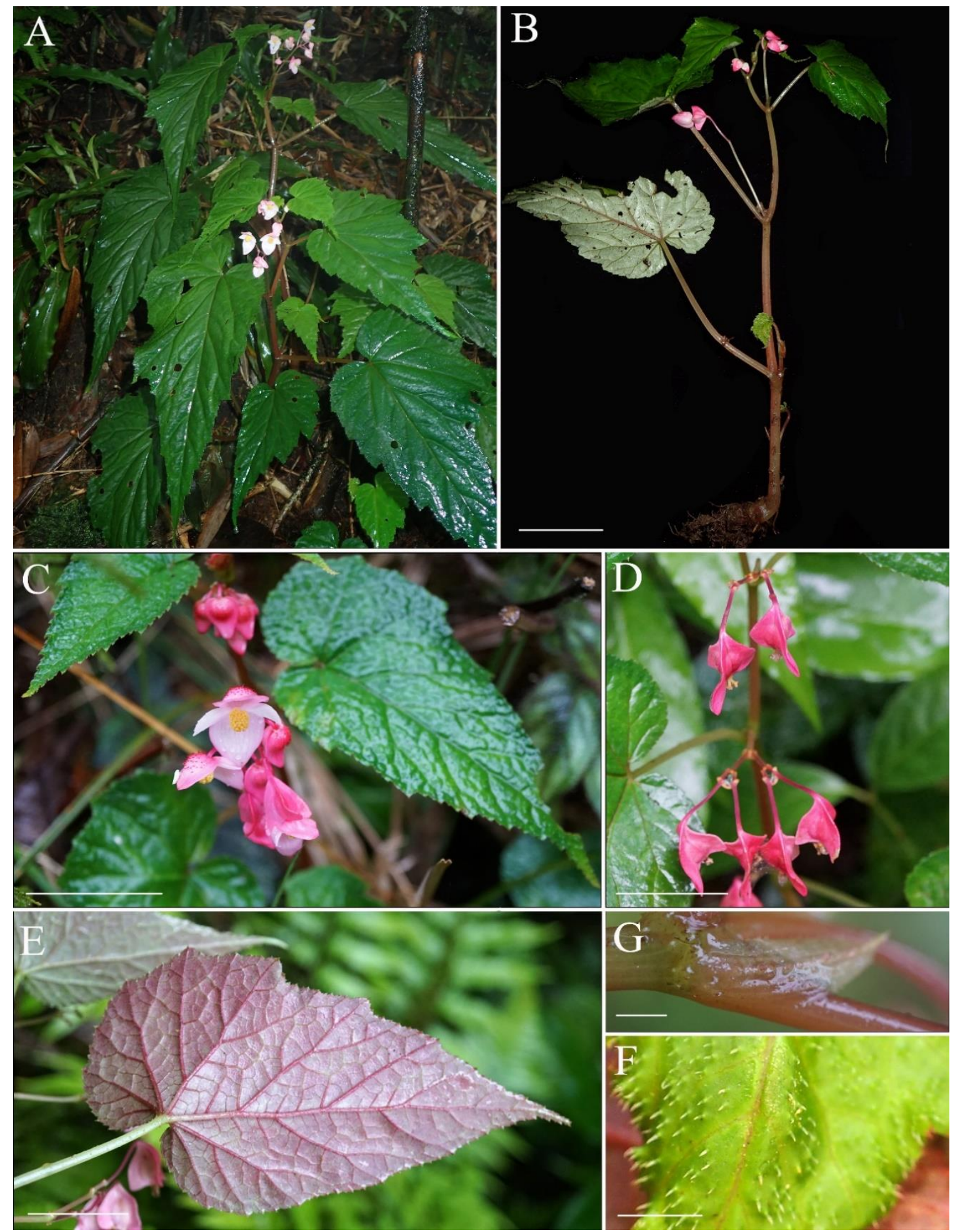

Figure 1. Begonia wenshanensis C.M. Hu ex C.Y. Wu \& T.C. Ku: (A) Habitat and habit, (B) fresh specimen, $(C)$ Upper part of the plant bearing inflorescences, $(D)$ upper part of the plant bearing fruits, $(E)$ abaxial surface of leaves, $(F)$ adaxial surface of leaves showing hairy, $(G)$ stipule. Bars: $B=5 \mathrm{~cm}$, $C-E=2 \mathrm{~cm}, F=5 \mathrm{~mm}, G=2 \mathrm{~mm}$. Photos by Trinh Ngoc Bon and Pham Thanh Trang 

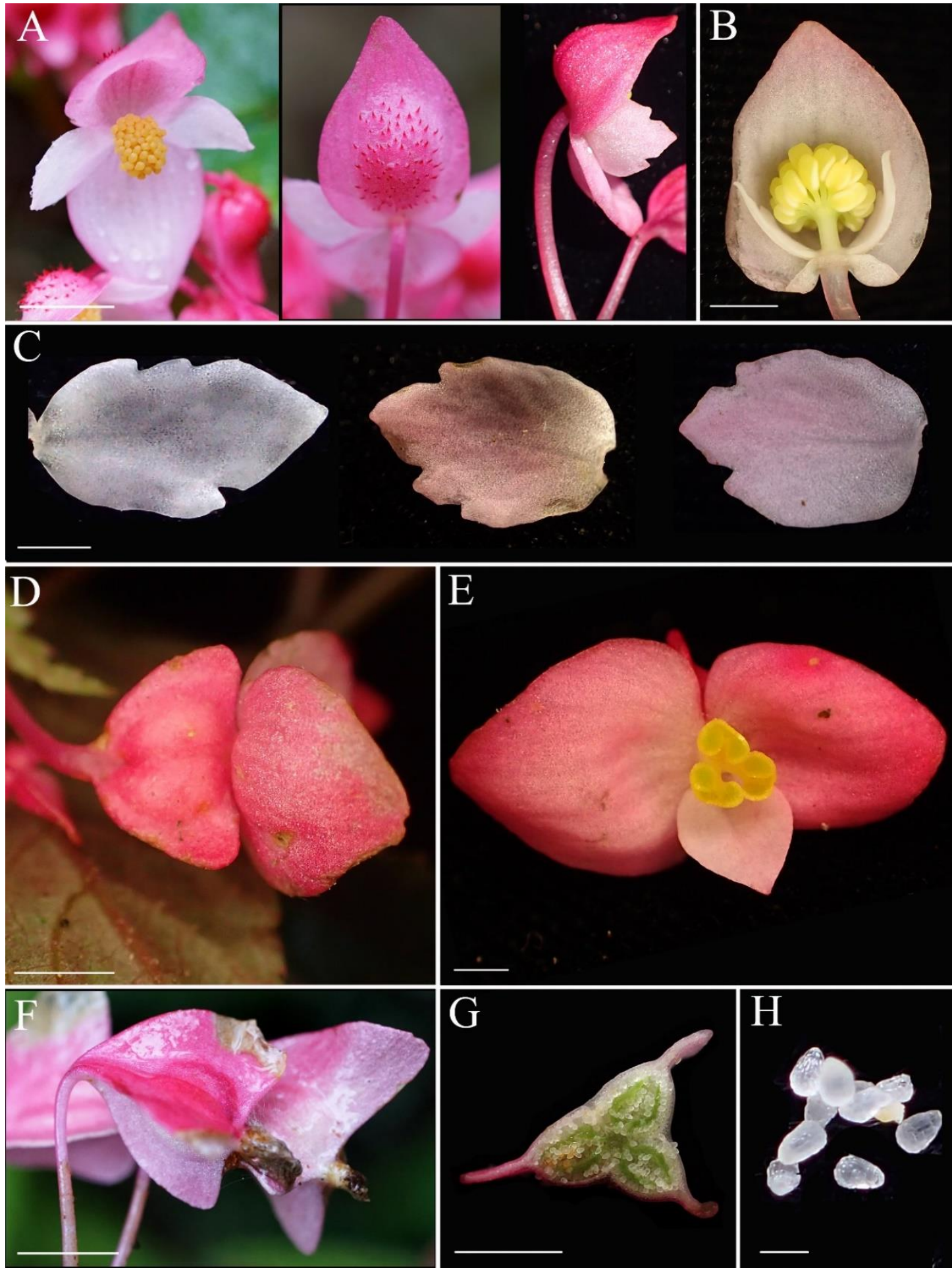

Figure 2. Begonia wenshanensis C.M. Hu ex C.Y. Wu \& T.C. Ku: (A) staminate flowers showing entire, hairy and glabrous petals, $(B)$ stamens, $(C)$ cleft margin of petals in staminate flowers, $(D)$ pistillate flower, side view, $(E)$ pistillate flower, frotal view, $(F)$ young fruits, side view, $(G)$ cross section of young fruit, $(H)$ seeds. Bars: $A, D, F, G=5 \mathrm{~mm}, B, C, E=2 \mathrm{~mm}, H=1 \mathrm{~mm}$. Photos by Trinh Ngoc Bon and Pham Thanh Trang 


\section{REFERENCES}

[1] M. Hughes, P. W. Moonlight, A. Jara-Muñoz, M. C. Tebbitt, H. P. Wilson, and M. Pullan, "Begonia Resource Center," 2018-Present. [Online]. Available: http://padme.rbge.org.uk/begonia/. [Accessed Apr. 13, 2021].

[2] D. Tian, Y. Xiao, Y. Tong, N. Fu, Q. Liu, and C. Li, "Diversity and conservation of Chinese wild Begonias," Plant Diversity, vol. 40, no. 3, pp. 75-90, 2018, doi: 10.1016/j.pld.2018.06.002.

[3] M. Hughes, An Annotated Checklist of Southeast Asian Begonia. London: Royal Botanic Garden Edinburgh, 2008, 164 pp.

[4] Y. M. Shui, W. H. Chen, H. Peng, S. H. Huang, and Z. W. Liu, Taxonomy of Begonias. Kunming: Yunnan Science and Technology Press, 2019, 468 pp.

[5] WFO, “Begonia L.," 2021. [Online]. Available: http://www.worldfloraonline.org/taxon/wfo4000004308. [Accessed Jun. 26, 2021].

[6] L. V. Averyanov and Q. H. Nguyen, "Eleven new species of Begonia L. (Begoniaceae) from Laos and Vietnam,” Turczaninowia, vol. 15, no. 2, pp. 5-32, 2012.

[7] W.-H. Chen, S. Radbouchoom, H. Q. Nguyen, H. T. Nguyen, K. S. Nguyen, and Y.-M. Shui, "Seven new species of Begonia (Begoniaceae) in northern Vietnam and southern China," PhytoKeys, vol. 94, pp. 65-85, 2018, doi:10.3897/phytokeys.94.23248.

[8] H.-B. Ding, M. B. Maw, B. Yang, S. Bouamanivong, and Y.-H. Tan, "An updated checklist of Begonia (Begoniaceae) in Laos, with two new species and five new records," PhytoKeys, vol. 138, pp. 187-201, 2020, doi: https://doi.org/10.3897/phytokeys.138.46718.

[9] V. T. Pham, Q. D. Dinh, V. C. Nguyen, N. B. Trinh, D. D. Nguyen, T. H. Nguyen, and C. W. Lin, "Begonia of Vietnam: An updated checklist, including a new species and a new record," Phytotaxa, vol. 507, no. 2, pp. 144-154, 2021, doi: 10.11646/phytotaxa.507.2.2.

[10] M. F. Gagnepain, "Begoniacées," in Flore générale de l'Indo-Chine, vol. 2, M. H. Lecomte, Ed., Paris: Masson, 1921, pp. 1095-1120.

[11] H. H. Pham, Cay Co Viet Nam. An Illustrated Flora of Viet Nam, vol. 1, Ho Chi Minh City: Tre Publishing House (in Vietnamese), 1999, pp. 577-588.

[12] V. T Pham, N. B. Trinh, K. L. Phan, and C. W. Lin, "Two new species, Begonia dinhdui and B. bacmeensis (Begoniaceae), from Vietnam," Phytotaxa, vol. 427, no. 1, pp. 22-30, 2019, doi: 10.11646/phytotaxa.427.1.3.

[13] C. W. Lin, T. C. Hsu, H. T. Luu, I. L. P. T. Nguyen, T. Y. A. Yang, and C. W. Li, "Revision of Begonia (Begoniaceae) in Bidoup-Nui Ba National Park, Southern Vietnam, including two new species," Phytotaxa, vol. 496, no. 1, pp. 77-89, 2021.

[14] C.-I. Peng, C.-W. Lin, H.-A. Yang, Y. Kono, and H. Q. Nguyen, "Six new species of Begonia (Begoniaceae) from limestone areas in Northern Vietnam," Botanical Studies, vol. 56, no. 9, 2015, doi: 10.1186/s40529-015-0089-3.

[15] C. M. Hu, C. Y. Wu, and T. C. Ku, “Begonia wenshanensis C.M. Hu ex C.Y. Wu \& T.C. Ku,” Acta Phytotaxonomica Sinica, vol. 33, no. 3, pp. 262-263, 1995.

[16] R. Liesner, Field techniques used by Missouri Botanical Garden. Missouri, 1995.

[17] K. Maden, "Plant collection and herbarium techniques," Our Nature, vol. 2, no. 1, pp. 53-57, 2004.

[18] B. Thiers, Index herbariorum: a global directory of public herbaria and associated staff. New York: New York Botanical Garden, 2015. 